\title{
Introduction
}

\section{Hanns Ullrich}

\section{THE PROGRAMME}

\section{A Subjective Approach}

The choice of 'The Evolution of European Competition Law' as the topic for the first conference of the newly established Academic Society for Competition Law was obvious enough. The interpretation, implementation and application of the rules of competition of the Treaty of the European Community (Art. 81 et seq. EC-Treaty) have undergone and continue to undergo profound changes, and they do so under American intellectual, industrial and political influence. An association with a predominantly European membership - inside and outside the European Union - but which looks across the Atlantic and seeks (and has) members there, probably may begin with a self-assessment of 'our' law. However, the nature and the narrow framework of a workshop - more had never been intended - required a rather selective and allowed a quite subjective approach. Thus, rather than to propose a reexamination of the modernization of enforcement ${ }^{1}$ or of merger control reform ${ }^{2}$ on the basis of a comparison with its US counterparts as suggested by predecessor projects of comparative competition law, ${ }^{3}$ the letter of invitation

1 Council Regulation 1/2003 of 16 December 2002 on the implementation of the rules on competition laid down in Article 81 and 82 of the Treaty, OJEC 2003 L 1, 1; Reg. 1/2003 has been implemented by a number of Commission Notices and Guidelines, all published in OJEC of 27 April 2004, No. L 101, at pp. 43 et seq., 54 et seq., 65 et seq., 81 et seq., 97 et seq.

2 Council Regulation 139/2004 of 20 January 2004 on the control of concentrations between undertakings (the EC Merger Regulation), OJEC 2005 L 24, 1; Commission Regulation 802/004 of 7 April 2004 implementing Council Regulation 139/2004 on the control of concentration between undertakings, OJEC 2004 L 133, 1; see also the Commission Notices in OJEC of 5 March 2005, Nr. $\S 56$ at p. 24 et seq. (simplified procedure), 32 et seq. (referral to national authorities).

3 H. Ullrich (ed.), Comparative Competition Law: Approaching an International System of Antitrust Law, Baden-Baden 1998; R. Zäch (ed.), Towards WTO Competition Rules, Berne 1999; J. Drexl (ed.), The Future of Transnational Antitrust - From Comparative to Common Competition Law, The Hague 201903.trich - 9781847201867 
to contributors of papers and to their commentators deliberately was based on my personal perception of the trends and reasons underlying the evolution of European competition law. This made me ask by way of a sub-title: 'Whose regulation, which competition?'

\section{Trends in the Community's Competition Policy}

There are several overlapping and interdependent trends that characterize the evolution of European competition law.

(i) One such trend is the shift in focus of competition policy, and, consequently, of the practical importance of the various areas of development and enforcement of the law. Privatization, de- and re-regulation of national public infrastructure sectors (telecommunications, air and railway transportation, energy) have not only allowed the Community to expand its regulatory competencies so as to largely overshadow reservations of Member States' powers as implied in Art. 86 EC-Treaty. Rather, it has established a broad new field of regulatory competition $\mathrm{law}^{4}$ which does not merely complement but rather has become an equal counterpart of the law against restraints of competition, and indeed may even be a rival body of law. ${ }^{5}$ Control of industrial concentration through mergers, acquisitions and joint ventures, ever since its belated introduction, ${ }^{6}$ has attracted more interest than control of contractual or otherwise concerted practices of restricting competition. This holds true both as regards administrative concern and political focus. In this regard, it suffices to compare the modes of control (ex ante/ex post) and the allocation of competencies between the Community and the Member States as provided for, on the one hand, by Regulation 1/2003 with respect to Art. 81 EC-Treaty and, on the other, by Regulation 4064/89, now Regulation 139/2004 as regards merger control. ${ }^{7}$ Whilst there may be

4 For an overview see E.J. Mestmäcker, H. Schweitzer, Europäisches Wettbewerbsrecht, 2nd edn, Munich 2004, 21 et seq.; Bundeskartellamt, Marktöffnung und Gewährleistung von Wettbewerb in der leitungsgebundenen Energiewirtschaft, available at http://Bundeskartellamt.de/wDeutsch/download/pdf/AKK02.pdf; summary in WuW 2003, 497; as regards telecommunications more specifically A. Bavasco, 'Electronic Communication: A New Paradigm for European Regulation', 41 CML Rev. 887 (2004).

5 See infra Part IV, in particular the comments by P. Nihoul on Chr. Kirchner, p. 300 et seq. with references.

6 Council Regulation 4068/89 of 21 December 1989 on the control of concentrations between undertakings, OJEC 1989 § 395, cm. OJEC 1990 § 257, 14.

7 References in footnotes 1,2 and 6 supra; as to the workload of the ${ }_{81847201867}$ 
good reasons for the differences of approach, these pertain less to the legal or economic nature of the transactions in question than to the politicoeconomic importance attributed to them. ${ }^{8}$ Even within the field of application of Art. 81 EC-Treaty the focus of control has been limited essentially to horizontal arrangements, and then mainly to hardcore cartels, leaving industrial cooperation largely unattended, if not privileged. ${ }^{9}$ Cooperation may, indeed, reach high market shares or, at least, need not be exposed to competition by more than two or three other groups. ${ }^{10}$

(ii) This redefinition of the fields with which competition policy is concerned of course has its nuances ${ }^{11}$ and tends to favour various forms

Commission in both areas (after modernization of enforcement, which aimed precisely, inter alia, at a more or less equal workload, see Commission, 'Report on Competition Policy 2004', SEC (2005) 805 final of 17 June 2005 at I.E (p. 56 et seq.), II D (p. 96 et seq.).

As regards differences of structural impact by concentration and by cooperation respectively these are generally overestimated: specialization, joint production, selling or purchasing, cooperative research and development do and are intended to reallocate resources in a no less irreversible way as it occurs in the case of mergers. (See also Commission, 'Guidelines on the application of Article 81(3) of the Treaty', OJEC 2004 L 101, 97 at no. 45.) EU (like German) competition policy does tend to level off the cartel/concentration gap by raising the threshold for control of cooperation rather than by lowering the thresholds for concentration control (see critically J. Schmidt, A. Fritz, 'Pro und contra Konzentrationsprivileg: Die unterschiedlichen Wirkungen von Kartellen und Fusionen auf Wettbewerb und Effizienz', in J. Kruse, O.G. Mayer, (eds) Festschrift E. Kantzenbach (Baden-Baden 1996), p. 119 et seq. The reason is presumably the problem of political acceptance of merger control by both industrial circles and governments relying on them.

9 Compare, in the first respect, the different definition of safe harbours for, on the one hand, horizontal restraints $(20 \%-25 \%$ combined market share according to Commission Regulation No. 2658/2000 (Art. 4) for specialization agreements and No. 2659/2000 (Art. 4) for joint research and development, No. 772/2004 (Art. 3(1)) for technology transfer agreements), and, on the other, for vertical restraints (30\% individual market share according to Commission Regulation No. 2790/99 (Art. 3) for vertical restraints generally, No. 772/2004 (Art. 3(2)) for technology transfer agreements); for the enforcement focus on hardcore cartels see Commission, 'Report on Competition Policy 2004', supra n. 7, at p. 7, 29 (Box 3); for the generous treatment of cooperation of all kinds see Commission, 'Guidelines on the application of Article 81 to horizontal cooperation agreements', OJEC 2001 L 3, 2 at no. 3 et passim; H. Ullrich, 'Competitor Cooperation and the Evolution of Competition Law: Issues for Research in a Perspective of Globalization', in J. Drexl (ed.), supra n. 3, p. 159 et seq. (sub II A2).

10 See Commission, 'Guidelines on horizontal cooperation agreements', supra n. 9, at nos. 36, 51, 71, 105, 134, 168, Commission, 'Guidelines on the application of Art. 81(3)', supra n. 8 at no. 116.

11 Thus, for example, Art. 4 Commission Regulation 2790/1999 of 22 December 1999 on the application of Article 81(3) to categories of vertical agreements and concerted practices, OJEC 1999L 336, 21 outlaws a number of traditional hardcore 9781847201867 
of market regulation. One such form is self-regulation by market actors. It seems to be the logical result of a looser antitrust regime which puts much trust in market control of private arrangements. An example of this is, when broad block exemptions of vertical agreements ${ }^{12}$ or technology transfer agreements ${ }^{13}$ leave the configuration of systems of distribution or of licensing, which before had been subject to a structured legal framework, ${ }^{14}$ to determination by the parties; that is typically to collective negotiations of model agreements between a manufacturer or an assembler and the distributors of products or suppliers of components.

Other examples of private regulation of competition by collective action are presented by standardization; ${ }^{15}$ by the exploitation of TV or radio and merchandizing rights by sports associations as well as by their practices of recruiting or transferring sportsmen/women and of admitting brokers, ${ }^{16}$ by the joint establishment of Internet market places, and

restrictions (resale price fixing, attribution of territorial exclusivities, albeit with considerable reservations; Commission Regulation No. 1400/2002 of 31 July 2002 on the application of Art. 81(3) of the Treaty to categories of vertical agreements and concerted practices in the motor vehicle sector, OJEC 2002 L 203, 30, seeks to loosen the grip of automobile manufacturers over distributors (comp. S. Vezzoso, 'On the Antitrust Remedies to Promote Retail Innovation in the EU Car Sector', ECLR 2004, p. 190).

12 See Commission Regulation 2790/1999, supra n. 11, and the contribution by D. Waelbroeck, 'Vertical agreements: 4 years of liberalisation by regulation n. 2790/99 after 40 years of legal (block) regulation', and the comments by W. Kerber, R. Zäch, Chapter 5 of this volume, at pp. 85 et seq.

13 Commission Regulation No. 772/2004 of 27 April 2004 on the application of Article 81(3) to categories of technology transfer agreements, OJEC 2004 L 123, 11 as compared to the Commission's predecessor Regulation 240/96 of 31 January 1996 on the application of Article 85(3) to certain categories of technology transfer agreements, OJEC 1996 L 331, 2; and see Commission, 'Evaluation Report on the Transfer of Technology Block Exemption Regulation Nr. 240/96 of December 2001' (available at http://europa.eu.int/comm/competition/antitrust/technology-transfer/en.pdf).

14 Frequently denigrated as a 'straight jacket' approach, but also defended as providing not only legal certainty, but also some backing in cases of unequal bargaining power in licensing negotiations, see $M$. Lejeune, 'Die neue europäische Gruppenfreistellungsverordnung für Technologietransfervereinbarungen', CR 2004, 467 at pp. 472,475 .

15 Commission, 'Guidelines on horizontal cooperation agreements', supra n. 9, at nos. 169, 172 favours standardization resulting from procedures involving substantial parts of the industry concerned or 'all competitors', apparently as an alternative to standardization by (semi-) official organization, ibid. at no. 162 .

16 See recently CFI of 26 January 2005, case T-193/02, Piau/Commission, WuW E EU-R 881; Commission of 19 January 2005, case DG Comp/C-2/27.214, Deutsche Bundesliga, WuW EU-V 1041; of 23 July 2003, case comp./C 2-27389-UEFA Champions League, WuW E EU-V-889; Commission, 'Report on Competition Policy 2004', supra n. 7, at nos. 84 et seq., 92 et seq. 
by the various types of mass-exploitation of intellectual property through pools ${ }^{17}$ or collecting societies. ${ }^{18}$ Their common feature is the group-wise internalization of at least some elements of the markets in question, and the institutionalization (typically due to more or less soft intervention by the competition authorities!) of some neutralization mechanism regarding the exercise of collective, in fact frequently, absolute market power. ${ }^{19}$ By contrast, the admission of many forms of industrial cooperation, such as teaming agreements, joint research and development or purchasing, is, at least in the more important cases, based on and satisfied by the mere existence of group competition. ${ }^{20}$ The common denominator, however, is the reversal of the role of competition: it is not the conditions of competition which determine the opportunities and limits of the market for individual enterprises, but it is the individual actors which, by joining forces or action, redefine their conditions of competition and, therefore, the market opportunities available to them.

(iii) Such reliance on private self-regulation and reversal of the role of competition may ultimately invite competition authorities to apply methods of regulatory control under Art. 81 EC-Treaty. Examples are the imposition of mechanisms of power neutralization, of duties of non-discrimination and of mandatory access. ${ }^{21}$ Whilst this may be only a means of last resort limiting the leniency of the antitrust regime established by a reinterpreted

17 See Commission, 'Guidelines on the application of Article 81 of the EC Treaty to technology transfer agreements', OJEC $2004 \mathrm{~L} \mathrm{101,2}$ at no. 210 et seq.

18 See recently Commission of 8 October 2002, case COMP/C-2/38.014, JFPJ 'Simulcasting', OJEC 2003 L 107, 58; Commission, 'Report on Competition Policy 2004', supra n. 7, p. 85 (Box 4); Commission, 'The Management of Copyright and Related Rights in the Internal Market', COM (2004) final sub 3., 3.4.

19 As regards standardization Commission, 'Guidelines on horizontal cooperation', supra n. 9, at nos. 163, 172 requires openness, transparency and representativeness of the standardization process; as regards technology pool building Commission, 'Guidelines on technology transfer agreements', supra n. 17 at no. 230 favours pools based on an institutional framework ensuring objectivity and transparency (for a critique see H. Ullrich, 'Patentgemeinschaften', in A. Fuchs et al., (eds), Festschrift U. Immenga, Munich 2004, 403, 423 et seq.; as regards sports rights, open and transparent licensing procedures (auctions) are considered to be countervailing remedies, see references supra n. 16 and ECJ of 27 September 2004, case C-470/02 P, EBU/ Commission, OJEC 2004 C314, affirming CF1 of 8 October 2002, case T-185/00, Métropole Télévision (M6)/Commission, Rep. 2002 I 3808.

20 See also supra n. 10.

21 See n. 19 supra and references therein; for open access to the use of standards Commission, 'Guidelines on horizontal cooperation', supra n. 9, at nos. 169, 174 et seq.; for access to pooled technology Commission, 'Guidelines on technology transfer agreements', supra n. 17, at nos. 224, 226, 231. 
Art. 81 EC-Treaty, a trend towards the application of prescriptive regulatory remedies more typically characterizes the enforcement of Art. 82 ECTreaty. Concern for safeguarding whatever potential for competition exists aside of the market dominating enterprises, as expressed in the formula of a specific responsibility for maintaining residual competion, ${ }^{22}$ becomes the point of departure for requiring dominant enterprises, particularly those controlling information markets, to open access to opportunities for more competition on adjacent markets or with complementary and even with diversified products. ${ }^{23}$

The 'philosophy' underlying this prescriptive approach seems to be borrowed from the justification for (re)regulation of liberalized/ privatized sectors where incumbent monopolists are subject to obligations to share assets with or to open market opportunities for both enterprises operating on adjacent markets and/or enterprises serving the same market. However, the origins of the problem and the basis for their solution are different. Re-regulation typically addresses problems of restructuring historically or naturally monopolistic markets by simulating competition-like constraints for the incumbent monopolist and by seeking to establish a basis for competition to begin on its market and/or on those markets which actually or potentially exist up- or downstream or which are or may be adjacent. By contrast, Art. $82 \mathrm{EC}$ is not concerned with challenging the dominant position as such, but only with its 'abuse'. Nevertheless, if it is relied upon as a basis precisely for issuing regulatory remedies in the interest of, inter alia,${ }^{24}$ market expansion in all directions, vertical or horizontal, then the reason must be that the efficient satisfaction of consumer welfare interests generally cannot be left to the control of a market dominating enterprise. Whatever the latter's merits, and notwithstanding the procedural ex post perspective,

22 See ECJ of 13 February 1979 case 85/76, Hoffmann-La Roche v. Commission, Rep. 1979, 461 at 541 (no. 91); of 11 December 1980, case 31/80, L'Oréal v. De Nieuwe Amck, Rep. 1980, 3775 at 3794 (no. 27); of 9 November 1980, case 322/81, Michelin v. Commission, Rep. 1983, 3461 at 3511 (no. 57), 3514 (no. 70); CFI of 30 September 2003, case T-203/01, Manufacture Française des Pneumatiques Michelin v. Commission, Rep. 2003 II 4071 at no. 97, and see also ECJ of 26 November 1998, case C-7/97, Oscar Bronner v. Mediaprint, Rep.1998 I 7791 at 7830 (no. 38): exclusion of 'all competition'.

23 See ECJ of 6 April 1995, cases C-241/91 P and C-242/91 P, RTE and ITP v. Commission, Rep. 1995 I 743 at p. 824 (no. 56); ECJ of 29 April 2004, case C-418/01, IMS Health v. NDC Health, WuW E EU-R 804 at no. 40 et seq.

24 Public interest concerns may inform the competition analysis, see J. Haracoglou, The Duty to Deal in Biopharmaceutical Industry: A Follow-on Innovation Perspective, EUI PhD-thesis Florence 2005. 
the likelihood, or possibly even only the risk, of forgoing future welfare gains, which renewed or reinforced competition promises, is unacceptable as a matter of maintaining a minimum of political and legal control over the competition system.

\section{A Strategic Orientation of Competition Policy?}

(i) The overall trend then is not simply a 'liberalization' of the scope, application and enforcement of the competition rules, but the operationalization of a deliberate strategy of realizing, in the interest of international competitiveness, ${ }^{25}$ the utmost of what the market may yield up to the limits of its working competitively. ${ }^{26}$ Such a strategic approach, ${ }^{27}$ whilst not always made explicit, is equally at the root of the recent revision of the concentration test in merger law, even though it may conflict with the aim of maintaining control over private market dominance. ${ }^{28}$ It may also be used to achieve objectives other than exclusively economic ones via the operation of the market, albeit within narrow limits. ${ }^{29}$ The novelty of this strategic orientation, however, lies less in the instrumentalization of the competition system for general or specific political goals, since this, in a way, may be implied in the role the Treaty assigns to the system of undistorted competition, or at least in the rival concepts of competition existing in economic and political theory. Rather, the novelty is in the rigour with which the strategic change is put into operation, precisely

25 See Commission, 'Report on Competition Policy 2004', supra n. 7, at p. 6 et seq., Commission, 'A Pro-active Competition Policy for a Competitive Europe', COM (2004) 293 of 4 April 2004.

26 In this respect see Commission, 'Guidelines on the application of Art. 81(3) of the Treaty', supra n. 7, at no. 105 is less revealing than at nos. 108, 114, 116, and, at any rate, is not as telling as the 'Guidelines on horizontal cooperation', supra n. 9

27 The term is used here in the traditional sense with no connotation of domestic favouritism, see also H.-W. Roth, 'Strategic Competition Policy - A Comment on EU Competition Policy', this volume Chapter 2, at p. 38.

28 Art. 2(2) (3) Regulation 139/2004 (the EC Merger Regulation), supra n. 2, whilst intended to allow a more flexible test of possible anticompetitive effects than the former dominance test (Art. 2(2) (3) Reg. 4064/89), in particular as regards non-dominant mergers, will also allow an 'efficiency defence' for mergers formally resulting in market dominance, see Recital 29 Reg. 139/2004, and for a discussion S. Mandhuit, T. Soames, 'Changes in EU Merger Control: Part 2', ECLR 2005, 75, 77; F.E. Gonzales Diaz, 'The Reform of European Merger Control: Quid Novi Sub Sole?', 27 (2) World Competition 177, 185 et seq. (2004); A. Pappalardo, 'Evolution récentes du contrôle des concentrations', J.T. (Droit eur.) 2004, 204, 207 et seq.

29 See Commission, 'Guidelines on Horizontal Cooperation', supra n. 9, at no. 179 et seq. regarding environment protection; for a broad discussion see C. Townley, Article 81: Putting Public Policy in its Place, EUI PhD-thesis Florence 2005 (to be pupublishedd). - 9781847201867 
because the pursuit of the goal of increased international competitiveness is an invitation to emulate the political rival's way of market regulation. ${ }^{30}$

Such rigour may have become more easily acceptable since the political, economic and legal environment of competition policy in the EU has changed considerably since the 'early days'. In particular, whilst due to EU enlargement and risks of recidivism of market actors, market integration remains a primary concern, ${ }^{31}$ protection of individual freedom and prevention of bargaining imbalances has in part lost political support, ${ }^{32}$ just as, for another part, it may have won sufficient recognition in general contract law or related rules of law. ${ }^{33}$

(ii) However, strategic rigour also has its price. There has been an alignment of Member States' competition law with the rules of competition of the Community, as required by Art. 3 Regulation 1/2003. Whilst on the face

30 As regards reform of merger control the discussion always and explicitly turned around the US-model of Sect. I Clayton Act, see M. Burgstaller, Marktbeherrschung oder 'Substantial Lessening of Competition', WuW 2003, 726; and in depth U. Denzel, Materielle Fusionskontrolle in Europa und den USA, Baden-Baden 2004, 68 et seq.; the claim is now made that a 'truly European solution' has been found, see Gonzales Diaz, supra n. 28, 27 (2) World Competition at p. 188 (2004). Whilst modernization of enforcement has many different roots, in its result it looks very much like a copy of the US system adapted to European needs (and with a number of imperfections), see C. Jones, 'A New Dawn for Private Competition Law Remedies in Europe? Reflection from the US', in Cl.-D. Ehlermann, J. Atanasiu (eds), European Competition Law Annual 2001: Effective Private Enforcement of EC Competition Law, Oxford 2003, 95 et seq.. The Commission's Guidelines on Horizontal Cooperation or on Technology Transfer, loc. cit., both are rather close to their US counterparts, see as regards the latter H. Ullrich, Patentgemeinschaften, supra n. 19, at p. 412 et seq.

31 See Commission, 'Report on Competition Policy 2004', supra n. 7, at p. 7, and note that under both Art. 81, 82 EC-Treaty and Art. 2(2) (3) Reg. 139/2004 the criterion of legality is the 'compatibility with the common market'.

32 This seems to be particularly true for the basic assumption that individual freedom is a precondition of competition that is put in peril whenever enterprises, by concertation or by concentration, reduce not so much their own freedom but that of the other actors on the market, see E.J. Mestmäcker, H. Schweitzer, supra n. 4, at pp. 72, 80. The 'neutralizing mechanisms' mentioned supra n. 19 seem to bring back some of this idea of freedom, but miss the point: it is not fairness within a group that counts, but freedom from that group.

33 One example are national rules against unfair competition, which Art. 3(3) Reg. 1/2003 expressly exempts from the Community's claim for priority of its competition rules, see Recital 9 Reg. 1/2003, the contribution by L. Boy, 'Abuse of market power: controlling dominance or protecting competition?', and the comment by $\mathrm{P}$. Behrens in Chapter 8 of this volume, see also H. Ullrich, Anti-Unfair Competition Law and Anti-Trust Law: A Continental Conundrum?, EUI Working Papers, Law No. 2005/01. 
of it this has been a matter of saving transaction costs for enterprises or of creating legal uniformity and certainty, most Member States have fallen into line by themselves. Merger control always was based on the one-stop-shop principle, and national enforcement zeal outside the hardcore areas is not to be feared. Thus, the imposition of mandatory uniformity is really a matter of maximizing the effects of the overall strategic orientation of Community competition policy. ${ }^{34}$ In fact, it also implies a transfer of power. Member States, whilst retaining their legislative competence in competition matters, have lost control over its substance. They are, as a matter of law, bound to fully and closely follow whatever direction is given to the Community's competition policy. That is, up to one ill-defined limit: ${ }^{35}$ the control of market power. Indeed, by reserving Member States' power to adopt or apply 'on their territory stricter national laws, which prohibit or sanction unilateral conduct engaged in by undertakings', Art. 3(2,2) Regulation 1/2003 not only allows Member States to lower the thresholds of intervention but also to develop their own concepts of abuse of market power. ${ }^{36}$ Thus, again, sovereign control over the exercise of private market power becomes the hard core of any competition policy.

(iii) Ultimately, Art. 3(2,2) testifies to the difficulties of establishing in practice a stringently conceived competition policy. However, claims for the centralization of competition policy and to a reserved national domain are not so much based on different views of the objectives of competition policy. There is a basic, albeit differentiated consensus that consumer welfare should have priority even if additional objectives may

34 Art. 10, 11, 15, 16 Reg. 1/2003 enable the Commission to impose the Community's political choices in everyday practice of decentralized enforcement; but see H.-W. Roth, this volume, Chapter 2, sub. 7.

35 Art. 3(2) Reg. 1/2003 uses the distinction between concerted practices and unilateral conduct as the connecting factor for the Community's claim to priority of its competition policy. This means that not only does the conduct of enterprises, whose dominance may result from lawful mergers, come under national control, but also all practices which fail to meet the contract/concertation-test of Art. 81, such as recommended prices, quantitative supply limitations etc.; see F. Wagner von Papp, Empfiehlt sich das Empfehlungsverbot? WuW 2005, 379, 380 et seq.; A. Klees, Europäisches Kartellverfahrensrecht mit Fusionskartellverfahren, Cologne 2004, 69 et seq., 73 et seq.

36 See Recital 8 Reg. 139/2003; the second proposition follows from the basic rule that enterprises enjoying absolute market power may hardly be treated less strictly under national law than enterprises possessing only relational market power. However, the matter is not settled, since the Community's policy under Art. 82, which is about to be redefined, risks being compromised by divergent national rules, see H. Ullrich, Anti- 
legitimately be pursued. Rather, such claims are based on divergent concepts of which competition will best serve these objectives and be socially acceptable. ${ }^{37}$ In part, these relate to a technical understanding of the operation and potential of the process of competition, as becomes apparent in controversies over how much residual competition is enough to check existing market dominance or how much competition is required to allow transition from regulatory to antitrust control. More generally speaking, however, they relate to the question of whether and how individual freedom should be guaranteed as a prerequisite to effective competition or, conversely, how protection should be afforded against the exercise of market power (as well as the extent of that protection). These are both matters about which the Community itself seems to worry when it asks for institutional or procedural safeguards against otherwise accepted group action ${ }^{38}$ or when it favours the - rather ambivalent - establishment of countervailing power. ${ }^{39}$ Could it be that this is no more than the last point of resistance against a total turn-around from the original defence against the cooperative or concentrative creation of private control over the market to public control merely of generally accepted market power? If so, this move would seem to be a rather desperate one for a Community that is not yet politically powerful.

\section{THE WORKSHOP}

Since these technical and societal aspects of a competition system are just as interrelated as they are interdependent with the definition of the objectives of competition policy, it is no surprise that the contributions to the workshop collectively demonstrate a much more differentiated picture of the evolution of EU competition policy than has been suggested here as a subjective working hypothesis. They do so by dealing with a number of topics, which have been selected and proposed by me with no less subjectivity, and certainly with no attempt to achieve comprehensiveness. ${ }^{40}$

37 A point which I have argued in more detail in H. Ullrich, 'L'ordre concurrentiel - Rapport de synthèse - ou "Variations sur un thème de Nice" ', in L'ordre concurrentiel - Mélanges A. Pirovano, Paris 2003, 663; see also B. McDonnell, D. Farber, ‘Are Efficient Antitrust Rules Always Optimal?', 48 Antitrust Bull. 807 (2003).

38 See supra text at n. 19.

39 See ECJ of 15 December 1994, case C-250/92, Gottrup-Klim v. DLG, Rep 1994 I 5641 at p. 5687 (no. 32); Commission, 'Guidelines on Horizontal Cooperation', supra n. 9, at no. 116, 134.

40 Thus, unfortunately, the changing interpretation and application of Art. 86(2) EC-Treaty, however relevant in the workshop's context, could not be,dealt with ngf ${ }_{81847201867}$ 
The title of the first session was aimed at a politically provocative comparison with US antitrust law as the model law for EU reforms, and the rival in regulatory competition, if indeed there is such a competition. Clifford A. Jones, ${ }^{41}$ and W.-H. Roth ${ }^{42}$ approach the subject from different angles, and M. Patterson $^{43}$ illustrates divergences between the systems by the recent example of the antitrust treatment of licensing transactions. Modernization of the enforcement of the EU competition rules has kindly been taken up as a subject and presented in the perspective of practice by G. Tesauro, ${ }^{44}$ then president of the Italian Autorità Garante della Concorrenza e del Mercato.

Vertical restraints were the point of departure for a revision of competition policy in both the US and the EU. D. Waelbroeck's, W. Kerber's and R. Zäch's different contribution and comments ${ }^{45}$ show that the law in this area, far from being settled, may need to be developed. But in what direction?

Horizontal agreements cover too many types of practices to be dealt with by one paper. They may not have been sufficiently analysed under the antitrust laws as regards, on the one hand, the interplay of networking and economic globalization, and on the other, the relationship between antitrust control of cooperation and of concentration. By an extensive factual and legal examination, and by broad complementary comments, M.M. Leitao Marques, A. Fuchs and D. Zimmer contribute to filling this gap. ${ }^{46}$

Nor is merger law a subject that can be examined in a meaningful way by one paper alone. The limits of an economics based standard of control might be reached when asking the question of whether media concentration may be assessed in the same terms as are mergers and acquisitions in any other business area, or whether additional or alternative criteria, possibly even a (sector-) specific procedure, need to be applied. L. Idot as the author of the report P. Kremmyda and U. Bernitz as commentators were guarantors of a lively discussion. ${ }^{47}$

An even more controversial discussion was bound to arise from the report of L. Boy on a proper Continental reading of Article 82 and from the comments by E. Fox and P. Behrens. ${ }^{48}$ It foreshadowed the controversies

could the application of Articles 10(2), 3(g), 81, 86 EC-Treaty to state involvement in cartelization/anti-competitive self-regulation be examined. The programme simply would have become too full.

41 Infra Chapter 1.

42 Infra Chapter 2.

$43 \quad$ Infra Chapter 3.

44 Infra Chapter 4.

45 Infra Chapter 5.

46 Infra Chapter 6.

47 Infra Chapter 7.

48 Infra Chapter 8. 
which are likely to arise as soon as the Commission publishes its new Guidelines on its reading of Article 82, a draft of which is expected by the end of 2005.

Using a non-conventional systematic approach, the analysis of Art. $82 \mathrm{had}$ deliberately been placed after the discussion of merger control and before the examination of competition-oriented market regulation so as to make the conceptual links and systemic contradictions between competition law and (re-)regulation of potentially competitive markets for infrastructure services more visible. This new counterpart of competition law merited much attention, as its raison d'être of ensuring an optimal as well as some universal supply of 'services publics' by way of, on the one side, imposed and, on the other, invited competition, raises the question whether it really is based on the same idea of competition which the antitrust laws protect. In a welfare economics, efficiency oriented perspective, the answer seems to be obvious enough. But the contributions by C. Kirchner and J. Monéger as well as the comments by K. Stockmann, F. Di Porto and by J. Fejø and P. Nihoul respectively seem to suggest that the law of (re-)regulation is still in too much of a state of flux to allow for a satisfactory answer at present. ${ }^{49}$

Instead of a conclusion D. Geradin gives an account of what efficiency claims mean in both EU competition law and sector specific regulation. ${ }^{50} \mathrm{G}$. Ghidini $^{51}$ in his final remarks introduces a number of additional value criteria into what otherwise might appear to be tantamount to a normative impoverishment of competition law.

Having been entrusted by Ascola with the main responsibility for the organization of the workshop, and as editor of the publication of the papers and written comments, which have been contributed to it, my sincere thanks go to all their authors. Their spontaneous and generous participation was at the heart of the success of the workshop as an academic meeting, and so was the spirit of frank and vivid discussion which all the participants brought to Villa Schifanoia. I am deeply indebted to all of them.

\footnotetext{
$49 \quad$ Infra Chapters 9 and 10.

Infra Chapter 11.

Infra Chapter 11.
} 